FAMOUS FIGURES

\section{Walter Reed USMC}

The Walter Reed Hospital and Centre, the M illbank of the United States Army Medical Corps, is an impressive place to visit. It is a building of history, dignity and worth. But who was the man it was named after? $\mathrm{H}$ is story is worth recounting.

Walter Reed came from a Methodist background and was a Southerner. The youngest of five children, one daughter and four sons, of the Reverend L emual Reed, he was born in a four roomed cottage in Gloucester, County Virginia on 13th September 1851. The family were truly Christian, read their Bibles daily and also the novels of Sir Walter Scott. Their family story is a happy and fulfilled one.

Ten years after his birth, abolitionists, and some Negroes, seized the US arsenal at $H$ arper's Ferry. The US government sent Colonel Robert $E$ Lee to put down the revolt. John Brown, the abolitionists' leader was arrested and then hanged. The Civil War then began. Although the $M$ ethodists had no part in slavery, they remained loyal to the South, and the Reverend Lemuel's two elder sons joined the C onfederate Army. The whole family later suffered with all the South when their revolt was lost. Their mother died, said to be worn out with the anxieties of the war. The pessimism and sadness, together with an aloofness which the young Walter acquired stayed with him all his life and he was never 'one of the boys'.

$\mathrm{He}$ decided to enter Virginia U niversity (which had been founded by Thomas Jefferson) to study medicine. That course, which included T heology, was much shorter than the Arts one, but a higher pass mark was demanded. M uch anatomy was insisted on, but it was said that there were no microscopes or clinical thermometers. A nother strange thing was that this degree course did not provide access to patients. For this, new graduates - MDs as the Americans continue to call them - had to travel to the big teaching hospitals in Baltimore, Philadelphia, Boston or to the corrupt city of $\mathrm{N}$ ew York. Just as happened here until the mid-fifties, a new medical graduate did not have to do any house training, but could put up his plate the day after graduation.

However, Reed wished to be properly trained. His moral background made him angry at watching the quacks arriving in their luxurious carriages together with coachmen and footmen, to do little more than glance at the patients. By contrast the hard working doctors in the Poor Law hospitals made little money and were little supported by

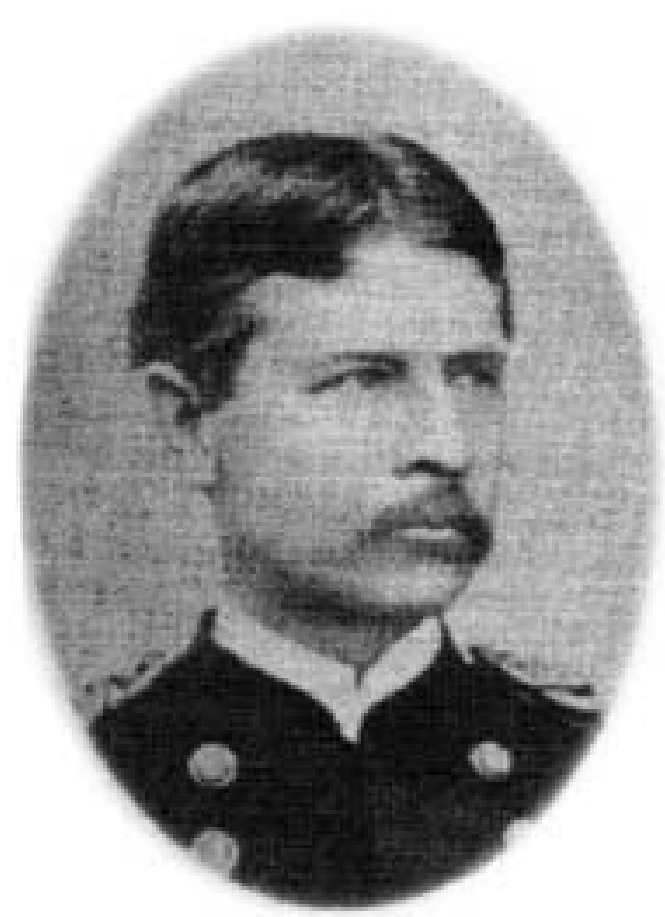

their generation of uncaring managers and politicians. It was, perhaps, his disaffection with what he saw in B ellvue H ospital, where he had begun his clinical training, and later in Brooklyn, that led him to revolt against civilian conditions. But Bellvue, which was one of the oldest medical schools, having been founded as long before as 1658 when members of the D utch E ast India C ompany of $\mathrm{N}$ ew Amsterdam had set aside space for care of the sick and old - again, moved by their own strict Protestant beliefs.

One thing Bellvue Hospital had which took Reed's eye was a 24 hour ambulance service. This had been organised by $\mathrm{Dr}$ William $\mathrm{H}$ ammond, Surgeon $\mathrm{G}$ eneral of the tiny Medical Corps, when the civil war began, and reflected his experience with the Union Army. Ten ambulances stood on duty at the hospital stables and set out at a gallop when an emergency was announced on the, still new, telegraph system. An M O went with the driver to deal with whatever the trouble turned out to be.

One other job Reed did enjoy was his appointment, at only 22 years of age, as Assistant Sanitary Officer of the Brooklyn Board of $\mathrm{H}$ ealth. At the same time he fell in love with $\mathrm{M}$ iss Emilie Lawrence, whom he met at church and who would later become his wife. Their marriage was true and theirs was a life long and faithful union. All these may have been factors in causing him to decide to undertake a new life which he believed was to be worth while and benefit his fellow men. T his was to join the Army M edical Corps.
143 G lasgow Road, Perth, PH 2 OLX 
Walter Reed was not unique in his decision to join the Army. Very many other young men were having the same idea. In late 1873 there were 500 candidates sitting the Army Medical Corps entrance examination, to fill 30 vacancies. The field was large, the places available small. The entrance tests lasted five hours a day for six days and included Greek, Latin, French, mathematics and history as well as medical subjects. He passed and his papers are preserved - they show his depth of knowledge and range of ability. Yet his acceptance letter commented that his 'acquaintance with foreign literature was not up to the expected standard'. How many today would have passed the examination which Reed sat? But now he could wear his ceremonial uniform complete with smart sword.

$\mathrm{H}$ is first posting was to Arizona. $\mathrm{H}$ is Commanding Officer told him his priority was to take the posting and not to get married - he had asked for leave to do this first. A fter a journey reminiscent of those of the NS Era he found himself at the harsh and uninviting frontier with its Aden-like dry and dusty climate. R eed actually asked Emilie to join him, which she did, also by horse carriage. M eanwhile, he grew a military moustache but he never acquired the more standard full beard sported by most medical officers of the time.

$T$ he usual run of postings for a junior $M O$ went on - Nebraska was succeeded by M ount Vernon Barracks in Alabama. M ost of his patients were Indians and, as ever, most diseases were infectious. The Army M Os were forbidden even to use the word 'tuberculosis', they had to call it 'pulmonary disease'. During this phase of Reed's service it was said that his honesty, and refusal to swear or tell tales, did not win him favour in the Officers' $M$ esses. $H$ is Southern background was also a cause of ill ease for some fellow officers. $\mathrm{H}$ e had the misfortune to have to watch more than one ruthless massacre of so-called 'rebellious Indians', including that of Little Big Horn, where a massacre of 21st century style proportions took place by the US Cavalry. Reed, now aged 40, and with a growing child, asked for a four month period to pursue scientific studies. The new Surgeon General, Jediah $\mathrm{H}$ yde Baxter was, most unusually for a senior rank of the time, eager to promote more regular officers into such a post. He agreed that Walter Reed should go to the new, year old, Johns Hopkins Hospital in Baltimore and study pathology and bacteriology. Reed described this as a 'stroke of kindly providence' and surely he was right. It was to be the turning point in his life.

At 'the Johns' Reed was suddenly made aware of the host of great advances and ideas from E urope - from Pasteur to L ister.
Now he learned what bacteriology and immunology were really about. He worked under $\mathrm{H}$ alstead and met William Osler. $\mathrm{H}$ ere he was also fortunate in meeting men who were not only highly intelligent, but had that so rare of qualities in academic places - absence of jealousy when a younger man showed high ability and promise. The academic part of Walter Reed's life now came to fruition. Yet another fortunate coincidence occurred. The new Surgeon General, George Stanberg, though he would be a good example of the senior officer who tried to claim credit due to his juniors, and of lesser intelligence himself, decided to establish an Armed Forces M edical School. Of course, who would be asked to work in its laboratory and museum, but Reed

$M$ ajor Reed needed an assistant and asked that James Carroll, whom he had got to know at the Johns Hopkins, be transferred to Washington. Carroll was an Irish working class man who, like so many others, had crossed to seek his fortune in the U nited States, joined the U S Army, was promoted Sergeant and then became what is now known as a male charge nurse. $\mathrm{He}$ had shown particular aptitude as a laboratory assistant. N ow they would work together over many years. C arroll, the older man, was at first happy to work under Reed's direction. H owever, in later years he felt hurt when he saw his contributions had been neglected and he had not been given credit for what he had done in the discoveries published after R eed's death. $\mathrm{He}$ is not alone in this (1).

From now onwards, Walter Reed became an accepted member of the scientific and social establishment, becoming a member of higher medical societies and taking part in their discussions over the whole range of epidemic diseases and their possible causes. At this time there was much argument over the use of animals for experimentation and Reed was appointed a member of the US Government's Joint Committee on vivisection. It was also known that experimental immunisation was commonly carried out on 'unclaimed children' in local authority orphanages. This was ironic, as will soon be seen.

Infectious disease was, of course, the most serious problem for the civil communities and especially for the Armed Services. On 18th December 1897, the British M edical Journal published Ross' monumental article on malaria and its parasite. Ross showed that the plasmodium underwent changes within the anopheles mosquito. Then it was discovered that the mosquito carried the causative agent, which then entered the patient's blood when bitten by it. Reed was one of the first in the US to demonstrate the parasite in human red blood cells.

In the United States the most dreadful 
infectious disease was yellow fever. It could appear at any place in summer and autumn; no one realised the significance of its absence during winter. The course of yellow fever was inexorable and death came after a frightening and short course. $\mathrm{H}$ undreds of thousands died of haemorrhagic 'black vomit' and were terrified to the point of madness. It was the special plague of the whole $\mathrm{N}$ orth A merican continent. F rom the first properly reported epidemic of Santa Lucia in 1604 a succession had followed. The attempt by the confident $\mathrm{F}$ rench to construct the Panama Canal in 1881 onwards was destroyed by the disease and de Lesseps himself was imprisoned in 1892 after financial scandals had become known.

The cause was hotly debated. Different schools of thought scorned their opponents. The 'yellow fever bacillus' was held by one school to be the cause and the name of Guiseppe Sanarelli was associated with this view. Reed and his military superior disagreed. Fomites and clothing, dirty baggage and patients' personal belongings were believed to be the carriers. The affair came to a head during the ill-fated war against Cuba.

There was a short phase of proposed colonisation by the U nited States which set out to conquer the island after one of their battleships was sent to 'protect American interests' during an internal uprising in 1895. An ultimatum was sent to Spain and troops were sent to 'clear out an illegal regime'. Plus ça change. The war took the armed forces by surprise as usual. In particular the Medical Corps was under strength with only 177 commissioned officers and 750 enlisted men; the politicans wished to send in an Army Corps. Although the US Army was soon successful it had overlooked the fact that it was right in the Yellow Fever season. There were only 1000 killed in combat, but nearly 21,000 sick with Typhoid fever, with a death rate of $7.6 \%$. Yellow fever during that July infected 2000 soldiers but its death rate was $80 \%$.

After a long period of argument, orders and counter-orders, angry utterances by high ranks and anger if their opinion was questioned sensibly by a junior or 'outsider' and attacks at the rival $M$ arine $M$ edical Service, a plan was agreed. It would take the form of a clinical trial. Reed was given authority to construct a special custombuilt camp where the trial was to be carried out. This was in Cuba and was approved by no less a person than Leonard Wood, US Governor of the Island. One Dr Carlos Finlay, the son of an expatriate Scottish father and Parisian mother, and born in Cuba, had insisted that the common household misquito Aedes augypti was the carrier of the causative creature, whatever it was. Like Reed, he did not believe in the bacterium theory. Reed undoubtedly learned from Finlay, it was a pity he did not give $F$ inlay more later acknowledgment.

In the first experimental camp the first thing was to exclude the role of fomites as the carrier. T he camp was filled with grubby objects. N ext Reed had to recruit sufficient volunteers to agree to be bitten by the mosquito. This was a major moral decision. At once the Spanish language paper of Cuba, Discussion, reported

'A rumour has reached us of a happening so horrible and so monstrous that we feel compelled to publish it - to those immigrants who remain for a short time in Tricornia (the Camp) is offered one dollar a day.. being taken in groups of 30 or 40 men... they are shut up in special habitations in which are released large numbers of mosquitos which have bitten individuals with yellow fever. The object of this study on humans is to find out if the contagion is due, or may be due, to the inoculation from these bites. If the workman takesill and dies the experiment has successfully demonstrated that the disease is indeed due to such an inoculation'.

$M$ ajor Reed had, however, made his plan with great care. He had consulted the Spanish Consul and made clear what the stakes were. He had had letters of consent written in Spanish, including an 'informed consent form'. In the long term it has to be said his project's importance did not completely mitigate what he was asking those men to do.

'T he undersigned understands perfectly well that in the case of development of Yellow Fever in him, that he endangers his life to a certain extent but it being impossible for him to avoid infection during his stay on this island he prefers to take the chance of contracting it intentionally in the belief that he will receive from the said Commission the greatest care and medical service'.

There were two parts of this experimental camp. In one part was the dirty chamber, filled with soiled bedding, excrement, blood and sweat. In this part three men, two private soldiers and one officer, were shut up for over a fortnight. In the other, and more comfortable part, were those who were to be bitten by specially grown mosquitoes. Reed did not ask any US soldier to take part, but one, Private John $\mathrm{E}$ $\mathrm{K}$ issinger, did so. It was said that Reed saluted him for his action. The experiment began early in $\mathrm{N}$ ovember.

The rest, as is often said, is history. Reed proved that the mosquito was the carrier of the causative organism of Yellow Fever. On 9th D ecember Reed wrote in triumph to his wife after $\mathrm{K}$ issinger had contracted the infection:

'R ejoice with me sweetheart, as a side from the diphtheria antitoxin and K och's discovery of theTubercle B acillus, this will be regarded as the most important work scientifically this century. 
I do not exaggerate and I would shout for very joy that $\mathrm{H}$ eaven has permitted me to establish this wonderful way of propagatingYellow Fever. It was Finlay's theory and he deserves much credit, but he did nothing to prove it, and it was rejected by all including $\mathrm{G}$ eneral Sternberg... its importance to Cuba and the United States cannot be estimated. $K$ ean says the discovery is worth more than the cost of the Spanish war, including lives lost and money expended'.
Walter Reed did not reach the highest rank in spite of his undoubted worth. $\mathrm{He}$ became unwell and died in $1902 . \mathrm{H}$ is widow received an inadequate pension.

\section{Reference}

1. Merlin Pryce (1902-1976) and Penicillin; an Abiding Mystery, Dr Emrys Wyn Jones and Professor R. Gareth Wyn Jones, Vesalius, Vol viii, No 2, D ecember 2002. 